\title{
Grzegorz Wojtkowiak*
}

\section{CHARAKTERYSTYKA SPÓŁEK WYCOFYWANYCH Z RYNKU KAPITAŁOWEGO W POLSCE}

\section{WPROWADZENIE}

Współczesne zasady wolnorynkowe sprawiają, że słowo efektywność odmieniane jest we wszystkich przypadkach. Cecha sprawności towarzyszyć powinna każdemu działaniu, a od czasów „Traktatu o dobrej robocie” T. Kotarbińskiego ${ }^{1}$, definiuje się ją za pomocą takich elementów, jak skuteczność, korzystność i ekonomiczność.

Wraz z przeobrażeniami otoczenia, ewolucją systemów, w których funkcjonują podmioty gospodarcze, zmieniają się również ich cele oraz sposoby ich osiagania. Powszechne dążenie do rozwoju i wzrostu, na przykład w czasach recesji, nie musi być działaniem optymalnym. Również strategie defensywne czy równoległe może okazać się skuteczne, korzystne i ekonomiczne.

Podobne zmiany dotyczą rynku kapitałowego i postrzegania go przez przedsiębiorców i inwestorów. Wielu autorów zwraca uwagę na zmianę spojrzenia na strategie organizacji. Tradycyjne podejście ukazywało bezwzględne dążenie przedsiębiorstw do zaistnienia na rynku kapitałowym. Doświadczenia nie tylko ostatniego kryzysu ujawniło jednak wiele przykładów braku efektywności spółek, wynikającego zarówno z problemów z nadzorem, jak i zmiany celów organizacji ${ }^{2}$.

Mimo odczytywania giełdy, jako jednej z wyższych form i przejawów gospodarki wolnorynkowej, wyjście z niej może okazać się korzystnym rozwiązaniem, drogą do dalszego rozwoju przedsiębiorstwa i zwiększania wartości dla jego interesariuszy - taka sytuacje będzie właśnie przedmiotem dalszych rozważań.

\footnotetext{
* Dr, Uniwersytet Ekonomiczny w Poznaniu.

${ }^{1}$ T. Ps zczołowski, Zasady sprawnego działania: wstęp do prakseologii, Wiedza Powszechna, Warszawa 1976, s. 9.

${ }^{2} \mathrm{H}$. R a s hid Kh a n, L. Vil an ova, S. H a s s a i r i, Effects of Private Equity Investment on the Decisions of European Companies to go Private: An Empirical Study, ,International Journal of Management" 2011, vol. 28, issue 2, s. 493.
} 
Artykuł ten stanowi kontynuację tematu podjętego w publikacji ,Wycofanie spółki z rynku kapitałowego jako opcja strategii wyjścia”. Powstał w wyniku dyskusji i cennych uwag oraz pytań uczestników konferencji „Przedsiębiorstwo na rynku kapitałowym” zorganizowanej w czerwcu 2013 r. przez Katedrę Analizy i Strategii Przedsiębiorstwa Uniwersytetu Łódzkiego. W pierwotnym tekście uporządkowano terminologię przedmiotu, usystematyzowano przyczyny wycofania spółek z giełdy, przedstawiono skalę prywatyzacji w Polsce oraz scharakteryzowano sposoby jej przeprowadzania. Przedstawiono również wybrane aspekty i cechy szczególne takich postępowań ,prywatyzacyjnych” powołując się na doświadczenia badaczy innych rynków - analiza ta wraz z podjętą dyskusją była przyczyną kontynuowania podjętego tematu.

Podstawowym celem podjętych badań jest scharakteryzowanie grupy spółek, które są dobrowolnie wycofywane z giełdy, a także sformułowanie wstępnych wniosków i hipotez dotyczących przyczyn oraz celów postępowania przedsiębiorstw i inwestorów.

Wycofanie z giełdy (ang. going private) będzie rozumiane jako zaprzestanie notowania akcji danej spółki na giełdzie papierów wartościowych i zniesienie jej dematerializacji ${ }^{3}$. Zgodnie ze wskazaniem z wcześniejszej publikacji, wycofanie będzie rozumiane również jako forma ,prywatyzacji” - zmiana formy własności $\mathrm{z}$ masowej, rozproszonej na indywidualną.

Artykuł oparto o badania własne autora obejmujące analizę populacji, a także analizę poszczególnych przypadków w zakresie: sprawozdań finansowych, raportów bieżących spółek (przed wycofaniem z obrotu) oraz informacji z portali specjalistycznych. Wykorzystano także wtórne dane statystyczne i dokonano przeglądu publikacji (w tym fachowych czasopism branżowych).

\section{DOBÓR I CECHY PRÓBY BADAWCZEJ}

Za podstawowy okres badawczy przyjęto przedział 1997-2011. Jest to okres, w którym w pierwotnej publikacji zaprezentowano ilość wejść i wyjść z giełdy, a jednocześnie przedstawiono strukturę powodów wycofania spółek z giełdy w tym okresie. Spośród tej grupy, celowo, ze względu na brak dostępu do danych, wykluczono spółki wycofane w konsekwencji ich upadłości. Z tej samej przyczyny w badaniu nie uwzględniono podmiotów łączonych lub przejmowanych przez inne - rozważeniu wówczas powinna podlegać skuteczność samej fuzji, efekty synergii, a także kondycja partnera w transakcji.

\footnotetext{
${ }^{3}$ Dla uproszczenia terminologicznego, w artykule wycofanie akcji z obrotu będzie uznawane za wycofanie z giełdy, mimo iż teoretycznie akcje mogą nadal pozostawać zdematerializowane.
} 
Pozostała grupa obejmuje spółki, które wycofano z giełdy poprzez:

- wyprowadzenie z obrotu,

- zniesienie dematerializacji,

- wykluczenie z obrotu,

- przymusowy wykup,

- decyzję WZA,

- wykluczenie z obrotu na rynku macierzystym.

Łącznie populacja spółek, które mogły podlegać badaniu objęła 52 podmioty, które wycofano z giełdy w okresie 1997-2011. Jednocześnie weryfikacja dostępności sprawozdań finansowych spowodowała, że bezpośredniej analizie podlegało jedynie 8 spółek.

Strukturę podmiotów według przyczyn wycofania z giełdy z oznaczeniem liczby badanych podmiotów przedstawiono na rys. 1 .

Liczba spółek wycofanych z obrotu z podziałem uwzględniającym powód wycofania (1997-2011)

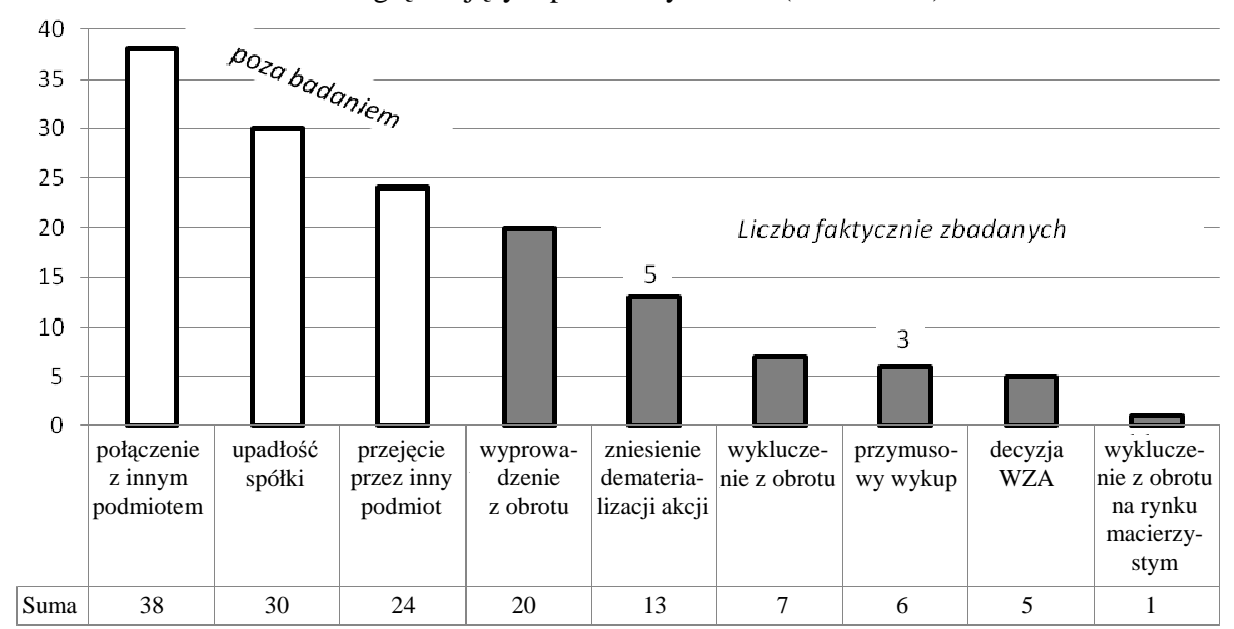

Rys. 1. Oznaczenie spółek podlegających badaniu według struktury przyczyn wycofania z GPW w Warszawie w latach 1997-2011

Źródło: opracowanie własne na podstawie danych z raportów statystycznych GPW.

Wielkość próby badawczej, wynikająca zarówno z dostępności danych, a także ze skali działania relatywnie młodego rynku papierów wartościowych, nie uprawnia do generalizowania wniosków. Osobną wartością może być jednak przedstawienie przykładów i odnalezienie spójnych cech charakterystycznych rynku w Polsce i na świecie, w tym także wskazanie praktyk postępowania Spółek oraz ich właścicieli i inwestorów. 


\section{DOŚWIADCZENIA Z GIEŁD ŚWIATOWYCH}

Zainteresowanie sposobami i scenariuszami wycofania akcji przedsiębiorstw z obrotu publicznego dotyczy wielu giełd światowych o znacznie dłuższej historii. Potrzeba zgłębiania wiedzy w temacie rośnie wraz ze wzrostem ilości wycofywanych przedsiębiorstw, co szczególnie zauważalne jest w okresie recesji czy kryzysu finansowego. Jeśli wejście na giełdę lub dodatkowe emisje nie przyniosą oczekiwanych efektów kapitałowych, wówczas naturalnym staje się poszukiwanie dróg rozwoju poza giełdą.

Definiując zatem szczegółowe obszary badawcze i metody analiz polskich przedsiębiorstw warto posłużyć się doświadczeniami rynków zagranicznych. Takie przykłady i porównania, pozwolą być może na odnalezienie lub zaadoptowanie skutecznych metod podnoszenia efektywności właśnie poprzez wycofanie $\mathrm{z}$ giełdy.

Przykładowo uwagę badaczy wzbudziła duża liczba przedsiębiorstw notowanych na giełdach w USA mających siedziby i prowadzących działalność w Chinach, które zostały wycofane z obrotu. Autorzy podczas analiz tych przypadków dążyli do wskazania prawnych uwarunkowań i utworzenia zarysów modelu pozwalającego na wybór odpowiednich ścieżek postępowania ${ }^{4}$. W prezentowanym kontekście, szczególną uwagę nabierał aspekt prawa międzynarodowego, ale również sposób sprawowania nadzoru na takimi transakcjami i metody (również prawne) chroniące interes mniejszościowych akcjonariuszy. Zakres badań prezentowanych $\mathrm{w}$ niniejszym artykule nie pozwoli na tworzenie podobnego modelu, ale ich poszerzenie powinno zmierzać do realizacji podobnych celów. Istotnym będzie także zwrócenie uwagi na potencjalne zagrożenia (i ewentualne ich wystąpienie) dla mniejszościowych akcjonariuszy.

Bogactwo przykładów czerpać można również z giełd azjatyckich. Przykładowo autorzy jednej z publikacji przeprowadzili analizę giełdy na Tajwanie ${ }^{5}$. Badania obejmowały lata 2002-2010 oraz przedsiębiorstwa, które dokonywała umorzenia akcji lub były wycofywane z giełdy. Wyniki pozwoliły na wskazanie cech charakterystycznych związanych z wyborem przedsiębiorstw: te, których rynkowa wartość akcji wskazywała niedoszacowanie (na podstawie wskaźnika P/E), przy jednoczesnych wyższych przepływach pieniężnych dążyły do zmniejszenia (umorzenia, skupu) akcji. Strategia wycofania $\mathrm{z}$ giełdy była charakterystyczna dla tych, w których występowali akcjonariusze mający większościowe pakiety akcji.

\footnotetext{
${ }^{4}$ P. Strecker, G. Puff, J. Tong, A private move, „International Financial Law Review”, July 2011, vol. 30, issue 6, s. 114 .

${ }^{5} \mathrm{Y}$. Hung-Ting, H. Y u - X u n, Ch. K a i e-ch i n, Empirical study on influential determinants for enterprise capital reduction: Evidence from cash reduction and stock repurchase, „International Journal of Organizational Innovation", Spring 2013, vol. 5, issue 4, s. 100.
} 
Rynki wschodnie pozwalają także na identyfikowanie zagrożeń związanych z potencjalnym poszkodowaniem akcjonariuszy mniejszościowych - szczególnie w sytuacji, gdy wycofanie $\mathrm{z}$ giełdy dotyczy podmiotów nieoszacowanych, czy takich, w których występuje spory poziom niejasności co do przyszłych perspektyw (co sugerowały wykorzystane dalej badania). Badania przeprowadzone na rynku papierów wartościowych w Hong Kongu pozwoliły na wskazania, że wycofanie z giełdy dotyczyło spółek odnotowujących dużą liczbę transakcji z podmiotami powiązanymi, w których podejmowano szereg działań negatywnie wpływających na ich wartość rynkową, w tym inicjowanych przez większościowych akcjonariuszy ${ }^{6}$.

Nieco inny obszar badawczy realizowany jest przy analizach rynku europejskiego. Przykładowo w wybranych wynikach wskazano różnicę w sposobie wycofywania spółek z rynku giełdowego w zależności od udziału funduszy typu private equity i bez ich udziału, z uwzględnieniem charakterystyki wykupów menadżerskich. Badania wykazały niejednorodność tych scenariuszy i zależności ich stosowania i pierwotnych przyczyn transakcji od poziomu niedoszacowania, struktury własności, wolnych przepływów pieniężnych oraz przewidywalności i jasności sytuacji (ang. visibility). Aktywność funduszy typu private equity występowała w sytuacji wyższego udziału w akcjonariacie inwestorów finansowych, przy zapotrzebowaniu na gotówkę i wyższym wskaźniku wypłaty dywidendy. Przypadki pozostałe dotyczyły raczej podmiotów niedowartościowanych, $\mathrm{z}$ dużą koncentracją właścicielską (dominujący akcjonariusz), wyższym poziomem generowania gotówki, ale i mniejszym poziomem przewidywalności i przejrzystości.

Analizując rynek europejski, szczególną uwagę należy zwrócić na wyniki badań rynku papierów wartościowych we Włoszech. Cechy charakterystyczne: struktura spółek notowanych na giełdzie i struktura inwestorów (znaczna liczba dużych i rodzinnych inwestorów) spowodowały, że po rozpoczęciu kryzysu finansowego w 2008 r. więcej podmiotów opuściło rynek niż dołączyło do publicznego obrotu akcjami.

W badaniach dotyczących rynku włoskiego (w latach 2001-2011 przebadano 53 wycofanych przedsiębiorstw), poszukiwano wskazówek mogących świadczyć o prawdopodobieństwie wycofania danej spółki z rynku kapitałowego. Zestawiono i scharakteryzowano również cechy charakterystyczne wycofywanych spółek, w tym przyczyny pierwotne i motywy wycofania ${ }^{8}$.

${ }^{6}$ J. D u, Q. He, S. W. Y u e n, Tunneling and the decision to go private: Evidence from Hong Kong, „Pacific-Basin Finance Journal”, April 2013, vol. 22, s. 50.

${ }^{7}$ H. Rashid Khan, L. Vil an ova, S. Has sairi, op. cit., s. 505.

${ }^{8}$ E. Laghi, I. Panetta, M. Tutino, All You Need is Cash? Empirical evidence on key factors in delisting process in Italy, Annual International Conference on Accounting \& Finance, 2013, s. 86. 


\section{CHARAKTERYSTYKA POLSKICH SPÓŁEK WYCOFYWANYCH Z GIEŁDY}

Wzorując się na pracach badaczy giełd o znacznie dłuższej historii i większej skali, przeprowadzono weryfikację wskazanej wcześniej grupy przedsiębiorstw. Ze względu na ograniczony dostęp do informacji, w tym również niekompletność okresowych sprawozdań finansowych przyjęto zasadę zgromadzenia przynajmniej:

- opublikowanych w rzetelnej formie (artykuły prasy branżowej i specjalistycznej, komunikaty giełdowe) przyczyn wycofania z giełdy, w tym wskazania potencjalnych inicjatorów zmian,

- sprawozdań finansowych $\mathrm{z}$ ostatniego roku przed rokiem wycofaniem $\mathrm{z}$ giełdy, $\mathrm{z}$ roku wycofania i roku po wycofaniu,

- danych dotyczących kształtowania się kursu giełdowego przed wycofaniem $\mathrm{z}$ giełdy (badanie niewykorzystane $\mathrm{w}$ niniejszej publikacji).

Informacje te, w zależności od konieczności wyjaśnienia tła procesu, rozszerzono o dostępne artykuły i komentarze prasowe, a także informacje z historii i późniejszej działalności Spółek. Prezentowane dane ze sprawozdań przeanalizowano, a na potrzeby niniejszego artykułu zawężono do: zmian poziomu inwestycji (poziomu aktywów trwałych) oraz zmian poziomu zadłużenia. Ze względu na zbyt krótki okres podlegający badaniu, w omawianych wynikach nie scharakteryzowano efektów co do skali przychodów i rentowności.

Jak zaznaczono, ograniczenia dostępu do danych nie pozwalają na uogólnianie wniosków, umożliwiają jednak wstępną charakterystykę próby, a także stawianie hipotez do przyszłej weryfikacji. Analizę rozpoczęto od weryfikacji przyczyn wycofania spółek $\mathrm{z}$ giełdy. W tab. 1 zestawiono badane spółki wraz ze wskazaniem pierwotnych powodów ich ,prywatyzacji”.

Wszystkie badane przypadki wycofania przedsiębiorstw z giełdy związane były z planami większościowego właściciela chcącego przejąć w całości kontrolę nad Spółką. Jednym z podstawowych celów wejścia na giełdę jest pozyskanie finansowania w celu rozwoju, czy zwiększenia skali działania. Zbadane przypadki wskazują, że paradoksalnie wycofanie z giełdy może służyć tym samym celom. Pozorną sprzeczność można wyjaśnić na podstawie przykładu.

Spółka WSIP została wprowadzona na giełdę papierów wartościowych w ramach procesu prywatyzacyjnego. Początkowo Skarb Państwa zrezygnował ze sprzedaży Spółki inwestorowi strategicznemu, jednak ostateczny plan prywatyzacji spółki przewidywał, że na podstawie księgi popytu na akcje, Ministerstwo Skarbu Państwa podejmie decyzję o sposobie sprzedaży firmy. Ostatecznie znaczącym inwestorem okazało się konsorcjum Advent International i CA IB PRE IPO Investment I. Na dzień prywatyzacji Spółka miała pozycję lidera na rynku, jednak systematycznie traciła udział w rynku - prywatyzacja była zatem szansą na bardziej dynamiczne zmiany. 
Badane spółki i przyczyny oraz krótka charakterystyka ich wycofania z giełdy

\begin{tabular}{|c|c|}
\hline Podmiot & Przyczyna \\
\hline $\begin{array}{l}\text { Wydawnictwo } \\
\text { Szkolne i Peda- } \\
\text { gogiczne SA } \\
\text { (WSIP) }\end{array}$ & $\begin{array}{l}\text { Nastapiło nabycie spółki przez Advent Internetional (fundusz Private Equity), } \\
\text { który dążył do objęcia } 100 \% \text { akcji i wycofania spółki z giełdy. W celu realizacji } \\
\text { spółka nabywała akcje własne w celu umorzenia a następnie Pahoa (podmiot } \\
\text { zależy od Adventu) ogłosił wezwanie (przymusowy wykup) na pozostałe akcje } \\
\text { będące w obrocie. }\end{array}$ \\
\hline TETA SA & $\begin{array}{l}\text { Teta spółka wytwarzająca oprogramowanie typu ERP została nabyta przez inwe- } \\
\text { stora branżowego (Unit4), który podjął decyzję o wycofaniu spółki z obrotu } \\
\text { publicznego. }\end{array}$ \\
\hline Optopol SA & $\begin{array}{l}\text { Nastapiło nabycie przez inwestora będącego jednym z największych producen- } \\
\text { tów sprzętu elektronicznego (CANON). Spółka po wycofaniu została podmiotem } \\
\text { zależnym i skupiła się na działalności w segmencie okulistycznego sprzętu dia- } \\
\text { gnostycznego. }\end{array}$ \\
\hline Prosp & $\begin{array}{l}\text { Hurtownia farmaceutyczna Prosper SA nabyta przez inwestora branżowego } \\
\text { firmę TORFARM SA. Podjęto decyzję o wycofaniu z giełdy. Pierwszy pakiet } \\
\text { akcji został nabyty od pierwotnego właściciela, w dalszej kolejności dokonano } \\
\text { wezwania na akcję spółki przejmowanej. }\end{array}$ \\
\hline $\begin{array}{l}\text { GG International } \\
\text { SA (GG) }\end{array}$ & $\begin{array}{l}\text { Spółkę nabyła grupa Nasper LTD. Zakup przeprowadzono przez spółkę zależną. } \\
\text { Nasper to inwestor branżowy zapewniający bogate know-how oraz dostęp do } \\
\text { finansowania. }\end{array}$ \\
\hline Praterm SA & $\begin{array}{l}\text { Globalna spółką Veolia Environnement kupila Praterm SA, jednego z większych } \\
\text { w Polsce prywatnych przedsiębiorstw ciepłowniczych. Przejęcia dokonano } \\
\text { poprzez spółkę zależną Dalkia Polska. }\end{array}$ \\
\hline $\begin{array}{c}\text { Polmos Lublin } \\
\text { SA }\end{array}$ & $\begin{array}{l}\text { Oaktree Capital management międzynarodowy podmiot zarządzający kapitałem, } \\
\text { w wyniku wezwania wykupił Polmos Lublin. Podjęto decyzję o wycofaniu } \\
\text { z obrotu. Obecnie oprócz Polmosu Lublin spółka posiada udziały w innym pro- } \\
\text { ducencie trunków wysokoprocentowych grupie Belveder. }\end{array}$ \\
\hline $\begin{array}{c}\text { Polmos Biały- } \\
\text { stok SA }\end{array}$ & $\begin{array}{l}\text { Central European Distribiution Corporation poprzez swoją spółkę zależną (Carey } \\
\text { Agri) nabyło Polmos Białystok. Kupno nastąpiło poprzez wezwanie. CEDC to } \\
\text { wcześnie największy producent wódki w Polsce, był też największym dystrybu- } \\
\text { torem i importerem napojów alkoholowych w Polsce i na Węgrzech. }\end{array}$ \\
\hline
\end{tabular}

Źródło: opracowanie własne na podstawie raportów giełdowych oraz doniesień prasy branżowej i specjalistycznej.

Zainteresowany inwestor branżowy, w konsekwencji większościowy właściciel, w ciągu dwóch lat podjął decyzję o wycofaniu Spółki z rynku giełdowego, co miało być szansą na przeprowadzenie znacznej inwestycji. Zarówno pierwsza prywatyzacja poprzez upublicznienie akcji i druga ,prywatyzacja” stanowiły znaczący skok w działalności Spółki.

Przykład ten pozwana na postawienie hipotezy, że osiagnięcie tego samego celu zależy od cech charakterystycznych i oczekiwań głównego właściciela lub inwestora. Jeśli rozwój (istnienie) danego podmiotu zależy od pozyskania kapitału, co może wymagać zadłużenia, wówczas zwiększenie ryzyka będzie mniej 
atrakcyjne dla inwestorów finansowych niż branżowych - w takiej sytuacji ci drudzy zdecydują się na wycofanie przedsiębiorstwa $\mathrm{z}$ giełdy.

Wstępnym potwierdzeniem hipotezy i jednocześnie rozwojowego celu wycofania spółek z giełdy jest zestawienie poziomu dalszych inwestycji. Na wykresie przedstawiono procentową zmianę poziomu aktywów trwałych.

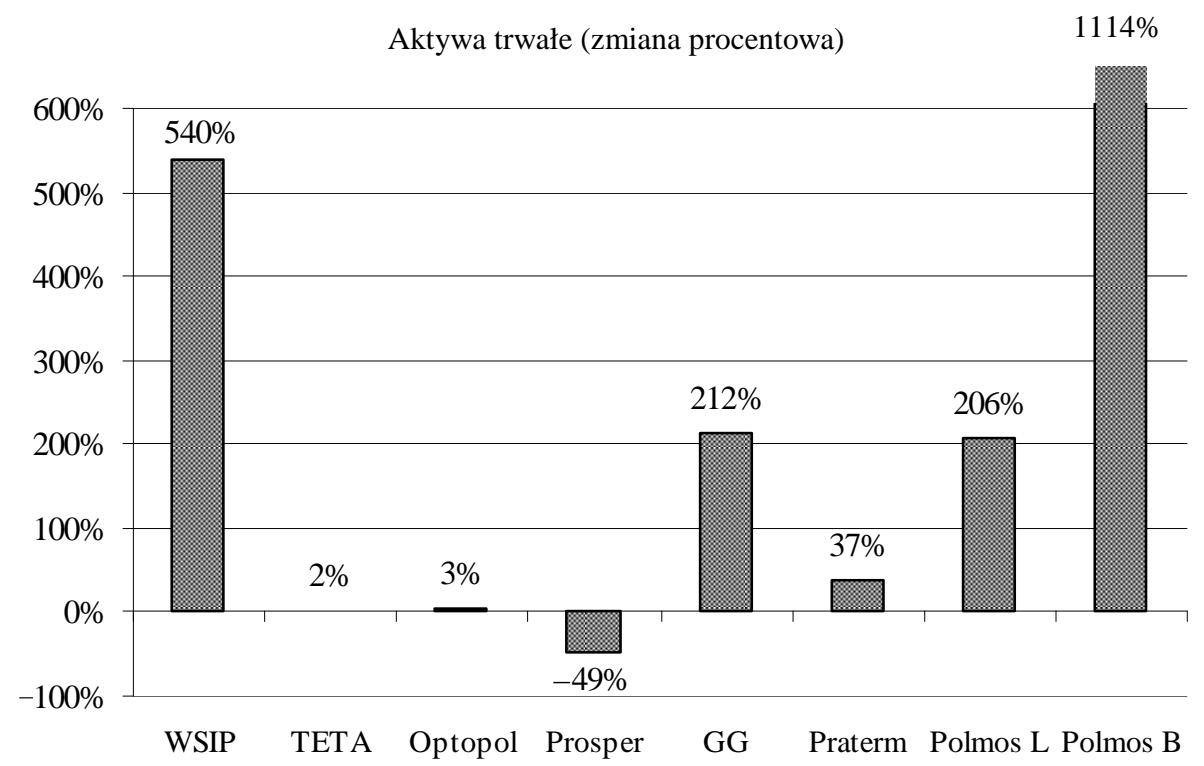

Rys. 2. Zmiana poziomu aktywów trwałych spółek wycofanych z giełdy, w rok po ich wycofaniu

Źródło: opracowanie własne.

Większość badanych spółek dokonała inwestycji, a połowa z nich znacznych inwestycji w aktywa długoterminowe (tylko spółka Prosper zmniejszyła poziom aktywów trwałych). Potwierdza to cele rozwojowe akcjonariuszy decydujących o wycofaniu podmiotów z giełdy.

Wyniki te należy porównać z badaniami prowadzonymi na rynku w Wielkiej Brytanii. Wskazują one przeciwne wnioski, wykazując powiązanie decyzji o wycofaniu $\mathrm{z}$ giełdy $\mathrm{z}$ planami ograniczenia inwestycji (przy jednoczesnym oczekiwaniu wzrostu rentowności) ${ }^{9}$.

${ }^{9}$ H. A s la n, P. Kumar, Lemons or Cherries? Growth Opportunities and Market Temptations in Going Public and Private, „Journal of Financial \& Quantitative Analysis”, April 2011, vol. 46, issue 2, p. 489 i 523. 
Kontynuując charakterystykę próby, zaznaczyć należy, że decyzje związane $\mathrm{z}$ wycofaniem nie były inicjowane przez zarządy, ale związane były z działaniami i planami większościowych i branżowych akcjonariuszy. Potencjalne wyjście zależeć będzie więc od struktury akcjonariatu i jego przekonań o efektywności i potencjale przedsiębiorstwa. Stwierdzić zatem należy, że w badanych podmiotach decyzje o wycofaniu przedsiębiorstwa z rynku kapitałowego należą do grupy strategii właścicielskich i relacyjnych ${ }^{10}$.

Ciekawym porównaniem będą tu wyniki badaczy wyspecjalizowanych w śledzeniu rynków kapitałowych, którzy zwracali uwage na oddziaływanie struktury właścicielskiej na wyniki ekonomiczne przedsiębiorstw (nawiązać tu warto do wspomnianych badań mówiących o zależności sposobu wycofania $\mathrm{z}$ giełdy od uczestnictwa funduszy typu private equity). W wyniku analiz pozytywnie zweryfikowano hipotezę o tym, że inwestorzy nie chcą pozbywać się kontroli nad dobrze prosperującymi przedsiębiorstwami ${ }^{11}$.

Podobnie na podstawie zbadanych przypadków można zgodzić się z teorią $^{12}$, że przyczyn pierwotnych wycofania z giełdy należy szukać wśród korzyści wynikających ze zmiany struktury kapitału. Wykorzystanie dźwigni finansowej, przy danych rozwiązaniach podatkowych i określonej początkowej strukturze kapitałowej, pozwoli na wygenerowanie dodatkowych oszczędności dla przedsiębiorstwa, a w konsekwencji również dla jego właścicieli. W większości badanych przypadków po „prywatyzacji” zwiększył się znacznie wskaźnik ogólnego zadłużenia - w szczególności w Spółce WSiP z 11\% do 94\%, w badanym okresie.

Powiązaną cechą charakterystyczną jest zatem również poziom ogólnego zadłużenia. Obecnie dla Spółek giełdowych wynosi on około $48 \%{ }^{13}$, przy czym w większości badanych spółek poziom ten był znacznie niższy przed wycofaniem $\mathrm{z}$ giełdy. Wzrost poziomu zadłużenia $\mathrm{w}$ roku następnym po roku zakończenia notowań jest jednak wyjątkowo znaczący - ukazano to na rys. 3 .

Skala badań i liczba podmiotów nie pozwala na wyciaganie wniosków, wynik sugeruje jednak postawienie hipotezy do przyszłej weryfikacji: jedną z istotniejszych przesłanek wycofania z giełdy jest możliwość realizacji znacznych inwestycji finansowanych kapitałem zewnętrznym, oraz potencjalne korzyści $\mathrm{z}$ tego wynikające.

${ }^{10}$ R. Krupski (red.), Zarzadzanie strategiczne. Koncepcje - metody, Wydawnictwo Akademii Ekonomicznej we Wrocławiu, Wrocław 1998, s. 36 i 40.

${ }^{11}$ Ł. T y rajski, Wptyw struktury wtaścicielskiej na efektywność działalności spótek notowanych na NewConnect, [w:] D. Zarzecki (red.), Czas na pieniqdz. Zarzqdzanie finansami. Mierzenie wyników przedsiębiorstw $i$ ocena efektywności inwestycji, Wydawnictwo Naukowe Uniwersytetu Szczecińskiego, Szczecin 2013, s. 319.

${ }^{12}$ Por. E. Lagh i, I. P a net t a, M. Tu ti in o, op. cit., s. 88.

${ }^{13}$ Zadlużenie spótek giełdowych. Czy można się ustrzec problemów?, Portal Gospodarczy WNP.pl, http://finanse.wnp.pl/zadluzenie-spolek-gieldowych-czy-mozna-sie-ustrzec-problemow, 206105_1_0_0.html [dostęp: 18.10.2013]. 


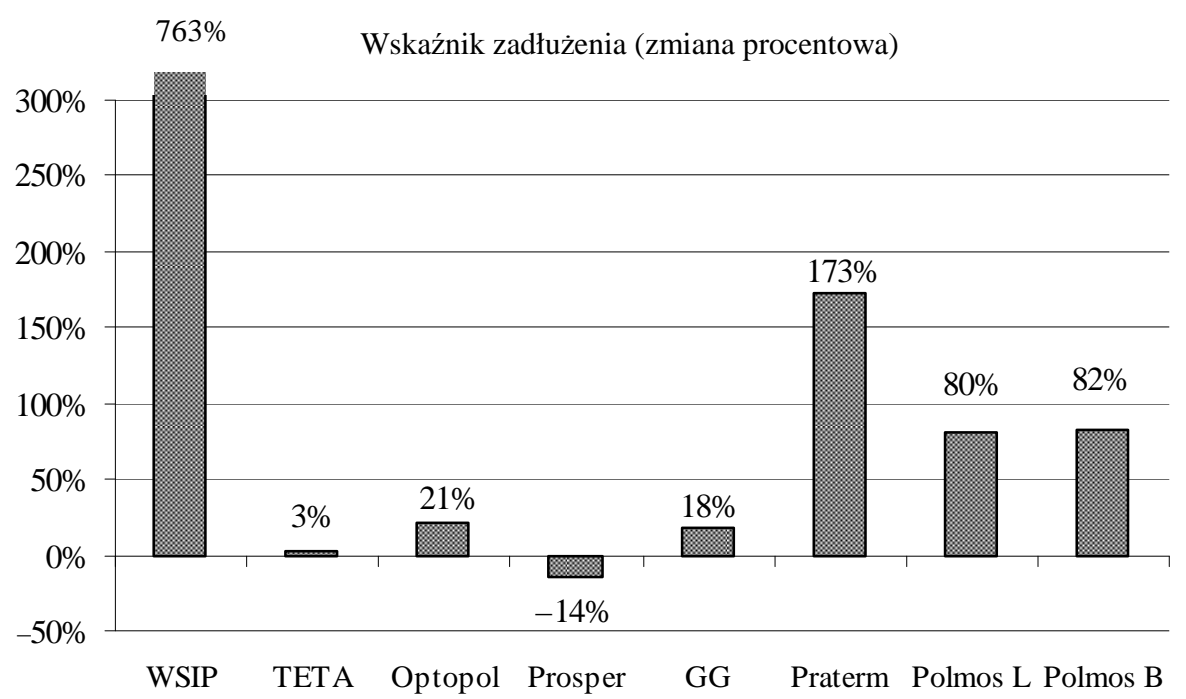

Rys. 3. Zmiana poziomu wskaźnika ogólnego zadłużenia spółek wycofanych z giełdy, w rok po ich wycofaniu.

Źródło: jak do rys. 2.

Jak wspomniano wcześniej, obecne zaawansowanie prac badawczych nie pozwala na charakterystykę efektów wycofania z giełdy w zakresie oceny zmian skali przychodów i rentowności. Wyniki te porównać będzie można w przyszłości z aspektami związanymi z potencjalnym niedoszacowaniem rynkowej wyceny spółek w okresie przed ich wycofaniem; szczególnie, że wyniki badań giełd zagranicznych wskazują właśnie niedoszacowanie jako jedną z przyczyn celowych ,prywatyzacji",

\section{ZAKOŃCZENIE}

Dynamika zmian na rynku powoduje, że opisane cechy badanej grupy mogą dotyczyć jedynie określonej sytuacji rynkowej, czy sytuacji danej branży. Wstępne wnioski należy zatem ograniczyć jedynie do badanych podmiotów, a przyszłe wyniki poszerzonych analiz i weryfikacji hipotez odczytywać w szerszym kontekście.

Zakres badań nie pozwala na zarysowanie pełnego modelu decyzyjnego wspierającego wybory przedsiębiorstw i akcjonariuszy (do czego dążyli wspo-

${ }^{14}$ Por. Q. He, T. Chong, L. Li, J. Zh an g, A Competing Risks Analysis of Corporate Survival, „Financial Management (Blackwell Publishing Limited)”, Winter 2010, vol. 39, issue 4, s. 1715. 
minani badacze rynków USA czy Azji), umożliwiło jednak na scharakteryzowanie próby i postawienie wielu hipotez.

Analizowane przypadki okazały się zaskakująco jednorodne, co do przyczyn wycofania z giełdy, poziomu realizowanych inwestycji i sposobów ich finansowania zadłużeniem. Przyszłe badania powinny dążyć do wyodrębnienia innych cech wycofywanych przedsiębiorstw i powiązania ich z zachowaniami inwestorów, a w konsekwencji z wartościami Spółek i efektami przyjętych strategii.

Planowana weryfikacja efektywności (zmiany poziomu przychodów i rentowności), a także historyczna ocena wartości, powinny także pomóc w dyskusji o poziomie ochrony mniejszościowych akcjonariuszy w takich transakcjach ${ }^{15}$ oraz wysokości premii dla właścicieli realizujących swoje strategie poza rynkiem publicznym.

Niemniej już obecnie zebrane wyniki i wnioski, a także wskazywane badania autorów zagranicznych, pozwalają na stwierdzenie, że wycofanie z giełdy może być traktowane jako jeden z naturalnych etapów lub scenariuszy na krzywej cyklu życia przedsiębiorstwa.

\section{BIBLIOGRAFIA}

A s la n H., Ku mar P., Lemons or Cherries? Growth Opportunities and Market Temptations in Going Public and Private, „Journal of Financial \& Quantitative Analysis”, April 2011, vol. 46, issue 2.

D u J., He Q., Y u en S. W., Tunneling and the decision to go private: Evidence from Hong Kong, „Pacific-Basin Finance Journal”, April 2013, vol. 22.

He Q., Chong T., Li L., Zh ang J., A Competing Risks Analysis of Corporate Survival, „Financial Management (Blackwell Publishing Limited)", Winter 2010, vol. 39, issue 4.

$\mathrm{Hung}$ - T ing Y., Y u - X u n H., K a i e - c h i n Ch., Empirical study on influential determinants for enterprise capital reduction: Evidence from cash reduction and stock repurchase, „International Journal of Organizational Innovation", Spring 2013, vol. 5, issue 4.

Krupski R. (red.), Zarzadzanie strategiczne. Koncepcje - metody, Wydawnictwo Akademii Ekonomicznej we Wrocławiu, Wrocław 1998.

Lag h i E., P a n et t a I., Tu t in o M., All You Need is Cash? Empirical evidence on key factors in delisting process in Italy, Annual International Conference on Accounting \& Finance, 2013.

Ps zc zołowski T., Zasady sprawnego działania: wstęp do prakseologii, Wiedza Powszechna, Warszawa 1976.

Raporty statystyczne GPW, http://www.gpw.pl/roczniki_gieldowe [dostęp: 5.11.2013].

Rashid Khan H., Vilanova L., Hassairi S., Effects of Private Equity Investment on the Decisions of European Companies to go Private: An Empirical Study, ,International Journal of Management" 2011, vol. 28, issue 2.

${ }^{15}$ Zainteresowanie tematyką jest również popularne u innych autorów. Por. V. Trivun, M. M rg u d, Protection of minority shareholders in transition economies: Lessons for B\&H, Conference Proceedings: International Conference of the Faculty of Economics Sarajevo (ICES), 2012, s. 963. 
Strecker P., Puff G., Tong J., A private move, „International Financial Law Review”, July 2011, vol. 30, issue 6 .

Trivu n V., Mrgud M., Protection of minority shareholders in transition economies: Lessons for $B \& H$, Conference Proceedings: International Conference of the Faculty of Economics Sarajevo (ICES), 2012.

T y raj s k i Ł., Wptyw struktury właścicielskiej na efektywność działalności spótek notowanych na NewConnect, [w:] D. Z ar z e c ki (red.), Czas na pieniadz. Zarzadzanie finansami. Mierzenie wyników przedsiębiorstw i ocena efektywności inwestycji, Wydawnictwo Naukowe Uniwersytetu Szczecińskiego, Szczecin 2013.

Zadtużenie spótek giełdowych. Czy można się ustrzec problemów?, Portal Gospodarczy WNP.pl, http://finanse.wnp.pl/zadluzenie-spolek-gieldowych-czy-mozna-sie-ustrzec-problemow,2061 05_1_0_0.html [dostęp: 18.10.2013].

Grzegorz Wojtkowiak

\section{THE CHARACTERISTICS OF THE COMPANIES WHICH ARE WITHDRAWN FROM THE STOCK EXCHANGE IN POLAND}

The article is a continuation of the subject brought up in the publication entitled: „Leaving of the stock exchange market as an option of the exit strategy". The main aim of the research is to characterize the group of companies, which are voluntarily withdrawn from the stock exchange, but also to formulate initial conclusions and hypotheses regarding the reasons and purposes of companies' and investors' activities. The article revises also the researches led by foreign authors and indicates the directions of future research in that area.

Key words: going-private, exit strategy. 